\author{
M.G. Shcherban," , A.D. Solovyev, A.O. Saliakhova \\ Perm State National Research University, Perm, Russia \\ (Corresponding author's e-mail: ma-sher74@mail.ru)

\section{The correlation between the surface-active characteristics of SAFOL 23 - alcohol - water systems and the length of the alkyl radical of the alcohol}

\begin{abstract}
The effect of isobutyl and isoamyl alcohols on the surface-active characteristics of SAFOL 23 nonionic surfactant was studied. The surface tension isotherms (STI) of an aqueous solution of surfactant and its wateralcohol compositions are obtained. The structure of mixed micelles and the values of the surfactant interaction factor in the micelle, based on the STIs of SAFOL 23 - alcohol - water systems, were calculated. The dependence of surface activity on the SAFOL 23: alcohol ratio passes through a maximum, which is associated with the transition of alcohol from co-surfactant to co-solvent due to the increase in its quantity. The wetting process of high dispersed polytetrafluoroethylene (PTFE) by SAFOL 23 - alcohol - water compositions was studied, contact angle isotherms were constructed. The PTFE surface was hydrophilized by compositions at ratios which comply with surface activity maximum. SAFOL 23 is more adsorbed on the surface of the solid phase than on the liquid-gas interface. The appending of alcohol into an aqueous solution of surfactant changes the ratio between hydrophilic and lipophilic groups of the composition, which affects cloud point. It significantly expands the range of application of surfactants and allows the use of SAFOL 23 as a solubilizer, emulsifier and wetting agent.
\end{abstract}

Keywords: nonionic surfactant, micellization, mixed micelles, surface activity, adsorption, contact angle, wetting, hydrophilic-lipophilic balance.

\title{
Introduction
}

Surfactants are organic compounds of diphilic structure, containing in their composition the polar and non-polar parts [1]. Surfactants concentrate on the phase interface due to its structure peculiarities, cause a decrease in surface tension and significantly change the properties of the interphase surface. In this regard, they play a very significant role in such practical processes as wetting, dispersion, emulsification.

Nonionic surfactants are one of the most widely used surfactant class in industry [2]. Ethoxylated alcohols, alkyl acetylene glycols, condensation products of glucosides with fatty alcohols, carboxylic acids, and ethylene oxide are of the greatest interest among nonionic surfactants [3].

Most surfactant compositions are mixtures, which include various solvents. The components of such systems interact with each other. As a result, their physicochemical and surface-active characteristics change. The efficiency of use of the compositions depends on the influence of many factors: product uniformity, resistance to temperature effects, viscosity, etc [4].

It is necessary to study the basic physicochemical dependences to understand the behavior of such systems under various conditions and their useful for solving specific problems.

This work is devoted to the study of the isobutyl (IBA) and isoamyl (IAA) alcohols effect on the surface-active characteristics of SAFOL 23 nonionic surfactant.

\section{Experimental}

The objects of research were aqueous and water-alcohol solutions of nonionic surfactant SAFOL 23 manufactured by Sasol Olefins \& Surfactants $\mathrm{GmbH}$. Its general formula is $\mathrm{C}_{\mathrm{n}} \mathrm{H}_{(2 \mathrm{n}+1)} \mathrm{O}\left(\mathrm{C}_{2} \mathrm{H}_{4} \mathrm{O}\right)_{7}$ where the carbon chain length $n=10-13$. The surfactant belongs to the class of ethoxylated alcohols, which have higher biodegradability and lower toxicity compared to the widely used ethoxylated nonylphenols [5].

The studied solutions were prepared in the concentration range of the mixture $0.02-130.00 \mathrm{~g} \cdot \mathrm{L}^{-1}$ for the mass ratios of the system SAFOL 23 - alcohol: 1:0, 1:4, 2:3, 3:2, 4:1, 1:0. We observed areas of foliation for compositions SAFOL 23 - IBA - water with a ratio of SAFOL 23:IBA = 1:4 and SAFOL 23 - IAA - water

\footnotetext{
${ }^{*}$ Corresponding author.
} 
with a ratio of SAFOL 23:IAA $=1: 4$ and $2: 3$ at concentrations of $40 \mathrm{~g} \cdot \mathrm{L}^{-1}$ and higher. We couldn ${ }^{\prime}$ include some results due to foliation of some compositions.

The surface tension of SAFOL 23 - alcohol - water, SAFOL 23 - water, alcohol - water, SAFOL 23 alcohol systems was determined by a handing drop method using a KRUSS DSA 25E tensiometer.

The value of the contact angle was measured by the lying drop method using the same device. It is impossible to wet powdered materials by direct methods, i.e. direct observation of a liquid drop on a particle. Therefore, we measured the contact angle by placing a liquid drop (diameter of $2 \mathrm{~mm}$ ) on a pressed polytetrafluoroethylene (PTFE) powder, achieving reproducible values. The properties of the pressed surface were considered similar to the properties of individual particles $[6,7]$.

The composition of mixed micelles, according to [8,9], was calculated by the formulas (1), (2):

$$
\begin{gathered}
1=\frac{x_{1}^{2} \ln \left(\frac{\alpha_{1} C_{12}}{C_{1} x_{1}}\right)}{\left(1-x_{1}\right)^{2} \ln \left(\frac{\alpha_{2} C_{1}}{C_{2}\left(1-x_{1}\right)}\right)}, \\
\beta=\frac{\ln \left(\frac{\alpha_{1} C_{12}}{C_{1} x_{1}}\right)}{\left(1-x_{1}\right)^{2}},
\end{gathered}
$$

where $\alpha_{1}$ and $\alpha_{2}$ are the mole fraction of SAFOL 23 and alcohol in mixture; $x_{1}$ and $x_{2}$ are the mole fraction of SAFOL 23 and alcohol in micelle; $C_{1}$ and $C_{2}$ is the CMC of SAFOL 23 and alcohol; $C_{12}$ is the CMC of SAFOL 23 - alcohol system. [9]:

The adsorption at the liquid-gas interface of SAFOL 23 was determined according to the formula (3)

$$
\Gamma_{L G}=-\frac{1}{R T} \frac{d \gamma}{d \ln C},
$$

where $R$ is the universal gas constant; $T$ is the temperature; $\gamma$ is the surface tension at the liquid-gas interface; $C$ is the concentration.

The adsorption isotherm at the solid-liquid interface in relative units, i.e. in comparison with the adsorption isotherm at the liquid-gas interface was determined by the formula (4) [9]:

$$
\Gamma_{S L}=-\Gamma_{L G}\left(\cos \theta+\gamma_{L G} \frac{d \cos \theta}{d \gamma_{L G}}\right),
$$

where $\gamma_{L G}$ is the surface tension at the liquid-gas interface; $\Gamma_{S L}$ and $\Gamma_{L G}$ are the adsorption at the solid-liquid and the liquid-gas interface.

The cloud point was determined according to ISO 1065-91 [10]. The method consists in heating an aqueous solution of surfactant with a $5 \mathrm{~g} \cdot \mathrm{L}^{-1}$ concentration to complete turbidity, cooling with continuous stirring, and determining the temperature at which the turbidity disappears.

The HLB of alcohols and a water-alcohol composition based on SAFOL 23 were calculated by using formulas (5)-(7) [11]:

where $t_{c}$ is the cloud point.

$$
H L B=0.098 t_{c}+4.020,
$$

$$
\sum H L B=\omega_{1} H L B_{1}+\omega_{2} H L B_{2},
$$

where $\sum H L B$ is the $H L B$ of the mixture system; $\omega_{1}$ and $\omega_{2}$ are the mass fraction of the components; $H L B_{1}$ and $H L B_{2}$ are the $H L B$ of individual components.

$$
H L B=\frac{20 M_{h}}{M},
$$

where $M_{h}$ is the molar mass of the $\mathrm{OH}$ group; $M$ is the molar mass of the alcohol.

\section{Results and Discussion}

Mixed micellization processes were studied for various SAFOL 23:alcohol ratios. We used pseudobinary approach, which consists of considering the ternary mixture as a binary [12]. The composition SAFOL 23 - alcohol was considered as the first component of the mixture, and water as the second. The surface tension isotherms (STI) of the examined ternary mixtures based on SAFOL 23 (Fig. 1) have the typical 
form for colloidal surfactants [13]: the surface tension decreases sharply at low concentrations of surfactants in the solution, but the curve reaches a horizontal plateau (the critical micelle concentration (CMC)).

A sharp reduce in surface tension at the low concentration range is associated with the formation of a monomolecular layer. The area almost parallel to the abscissa axis corresponds to the transition of surfactant molecules into the solution volume and the formation of micelles, initially spherical, then cylindrical.

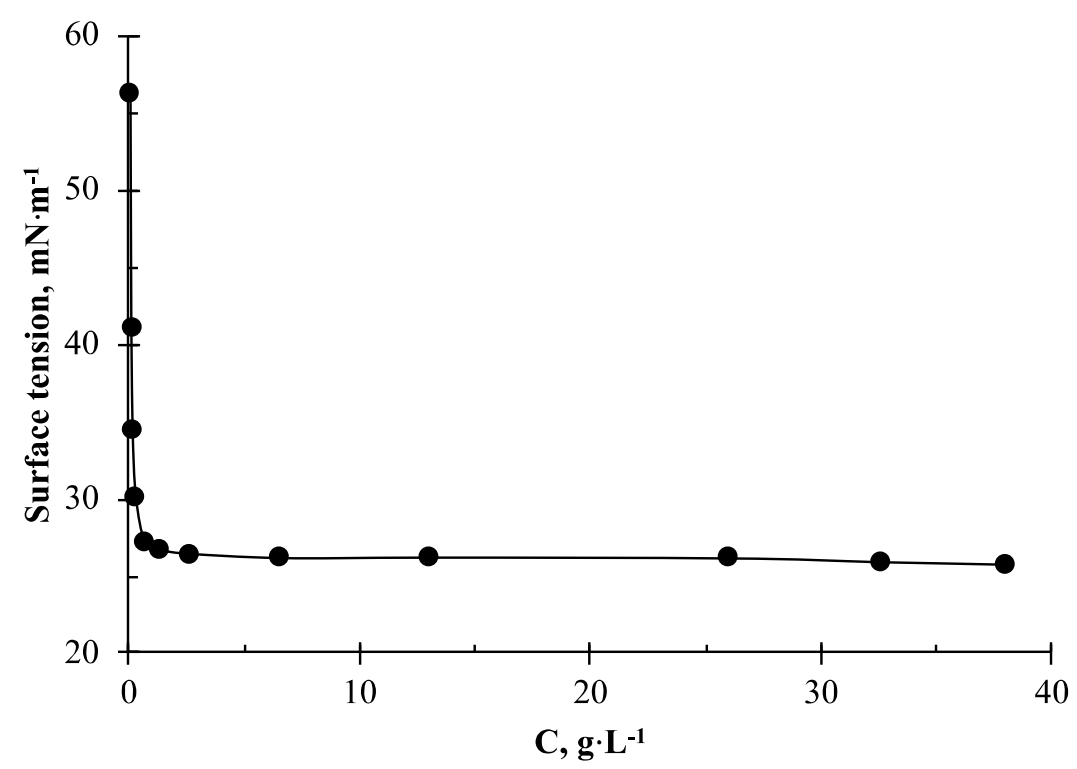

Figure 1. The surface tension isotherm of the water-alcohol composition SAFOL 23 (SAFOL 23:IBA = 3:2)

The surface-active characteristics of the individual compounds and their mixtures are presented in Table 1. The CMC were determined by the universal method for all surfactants - the concentration corresponding to the kink on the surface tension isotherm in semilogarithmic coordinates. Surface activity was calculated as the tangent of the slope of the initial portion of the STI.

Table 1

Surface-active characteristics of compositions

\begin{tabular}{|l|c|c|c|}
\hline \multicolumn{1}{|c|}{ Composition } & $\gamma_{\min }, \mathrm{mN} \cdot \mathrm{m}^{-1}$ & $\mathrm{CMC}, \mathrm{g} \cdot \mathrm{L}^{-1}$ & $\mathrm{G}, \mathrm{mN}^{-1} \mathrm{~m}^{2} \cdot \mathrm{kg}^{-1}$ \\
\hline SAFOL 23 - water & 26.45 & 0.27 & 5.05 \\
\hline IBA - water & 25.81 & 8.80 & 290.51 \\
\hline $\begin{array}{l}\text { SAFOL 23 - IBA - water } \\
\text { (SAFOL 23:IBA = 3:2) }\end{array}$ & 24.91 & 0.17 & - \\
\hline SAFOL 23 - IAA & 27.76 & - & 14.16 \\
\hline IAA - water & 30.12 & 3 & 218.83 \\
\hline $\begin{array}{l}\text { SAFOL 23 - IAA - water } \\
\text { (SAFOL 23:IAA = 3:2) }\end{array}$ & 23.97 & 0.22 & - \\
\hline SAFOL 23 - IAA & 25.16 & - & - \\
\hline
\end{tabular}

Figures 2, 3 show the STI of the SAFOL 23 - alcohol - water systems (SAFOL 23:alcohol = 3:2), SAFOL 23 - water, alcohol - water, SAFOL 23 - alcohol in semilogarithmic coordinates. The curves show us, that the studied alcohols are not surface-active, however, their appending into the SAFOL 23 solution promotes an increase in the surface activity of the mixture in comparison with an individual surfactant. This phenomenon is associated with the formation of mixed micelles and a synergistic effect [14].

The compositions of mixed micelles and the values of the surfactant interaction factor $\beta$ in the micelle were calculated by formulas (1) and (2) using the Rosen and Rubin method [8,9]. The results are presented in Table 2. The interaction factor $\beta$ is a quantitative characteristic of molecular interactions between surfactants in mixed micelles and, in the case of negative values, corresponds to the mutual attraction of the components in the mixture. 


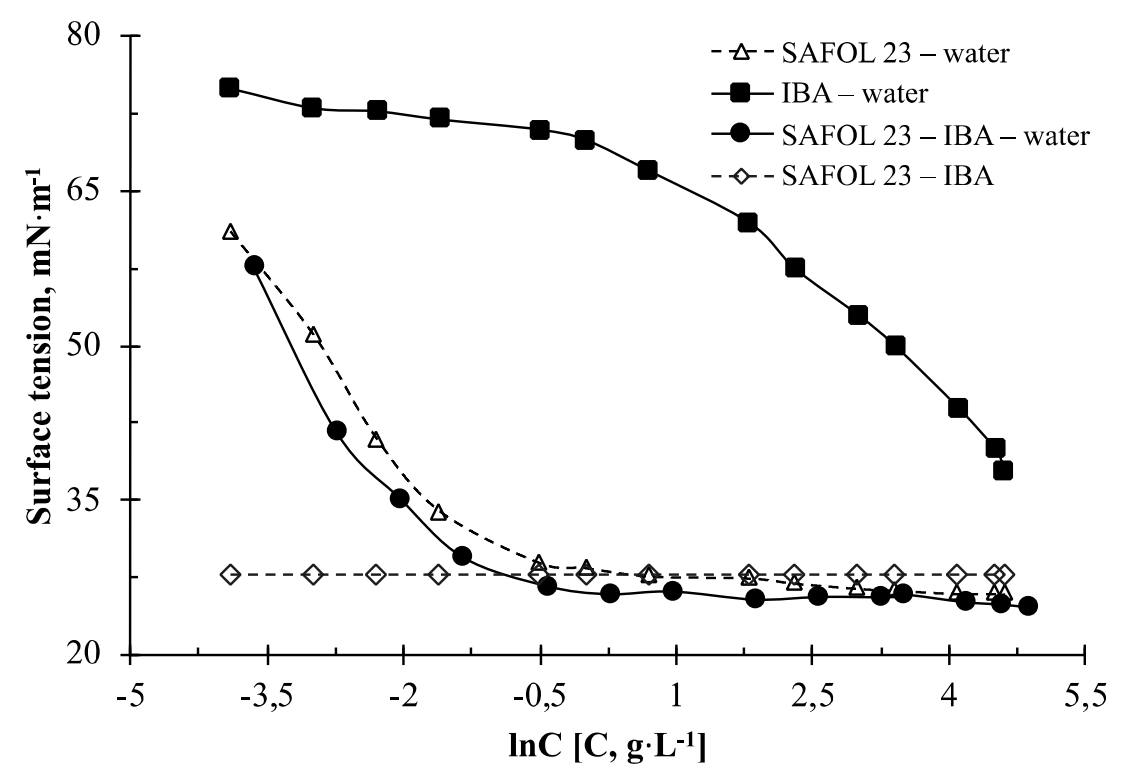

Figure 2. The surface tension isotherm of water-alcohol compositions based on SAFOL 23 and IBA

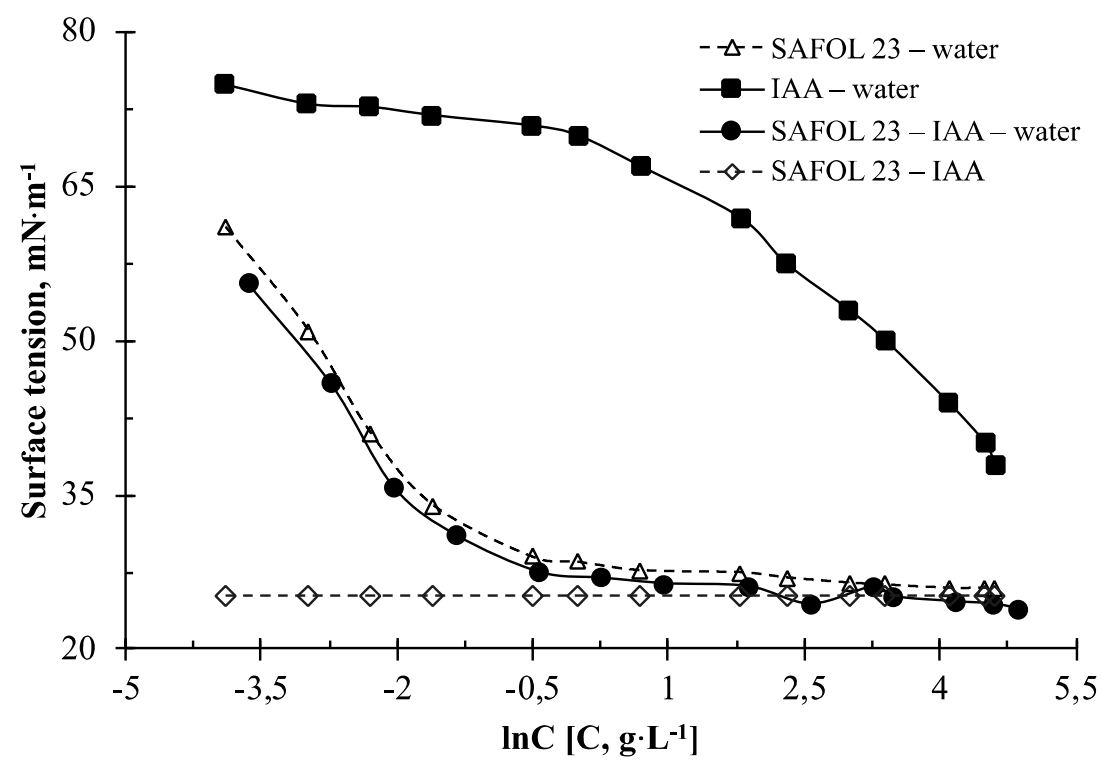

Figure 3. The surface tension isotherm of water-alcohol compositions based on SAFOL 23 and IAA

It is known that synergism during micellization in surfactant mixtures can be discussed under two conditions: $\beta<0,\left|\ln \left(C_{1} / C_{2}\right)\right|<|\beta|-$ what is done in our case, i.e. alcohol behave itself as a co-surfactant and is incorporated into the micelles in this concentration range.

In all cases the dependence of surface activity on the mole fraction of surfactants is extreme (Fig. 4), while with rising radical length the surface activity of the corresponding compositions falls, and the position of the maximum shifts toward a higher surfactant content in the mixture. The force of attraction between the molecules of SAFOL 23 and the alcohol also slightly decreases with increasing length of the radical.

The similar dependence was observed by N.A. Lyapunov in the study of the surface activity of cationic surfactants in the presence of ethyl alcohol [15]. This dependence can be explained by starting from a certain concentration, the alcohol does not behave as a co-surfactant, it behaves as a co-solvent, causing the disaggregation of micelles. In addition, there is no need for the aggregation of surfactant molecules into micelles when dissolved in alcohol, because the solvent contains hydrophilic and hydrophobic groups. 
The correlation between the surface-active characteristics ...

Table 2

The results of the study of the composition of mixed micelles SAFOL 23 - alcohol

\begin{tabular}{|c|c|c|c|c|}
\hline $\begin{array}{c}\text { Mass ratio } \\
\text { SAFOL 23:alcohol } \\
\end{array}$ & $\begin{array}{l}\text { Molar fraction of surfactant } \\
\text { in the mixture } \alpha_{1}\end{array}$ & $\begin{array}{l}\text { Molar fraction of surfactant } \\
\text { in the micelle } x_{1}\end{array}$ & Interaction factor $\beta$ & $\mathrm{G}, \mathrm{mN} \cdot \mathrm{m}^{2} \cdot \mathrm{kg}^{-1}$ \\
\hline \multicolumn{5}{|c|}{ IBA } \\
\hline $2: 3$ & 0.082 & 0.974 & -151.61 & 69.88 \\
\hline $3: 2$ & 0.168 & 0.890 & -74.19 & 290.51 \\
\hline $4: 1$ & 0.349 & 0.935 & -108.19 & 235.15 \\
\hline \multicolumn{5}{|c|}{ IAA } \\
\hline $3: 2$ & 0.600 & 0.813 & -41.33 & 218.05 \\
\hline $4: 1$ & 0.800 & 0.935 & -59.64 & 184.83 \\
\hline
\end{tabular}

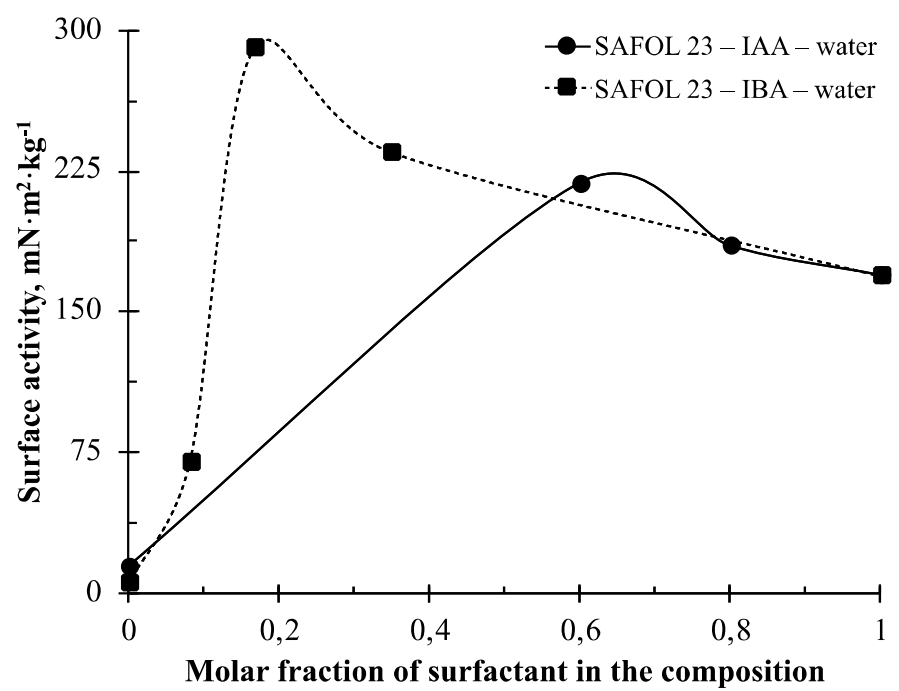

Figure 4. The influence of alkyl radical length of the alcohol on the surface activity of the composition based on SAFOL 23

The wetting characteristics of powder materials play an important role and are used to evaluate the effectiveness of processes such as wet dust collection, dust suppression, flotation, filtering, clumping of powder materials, molding of ceramic compositions, impregnation, road construction, production of gunpowder, printing [16].
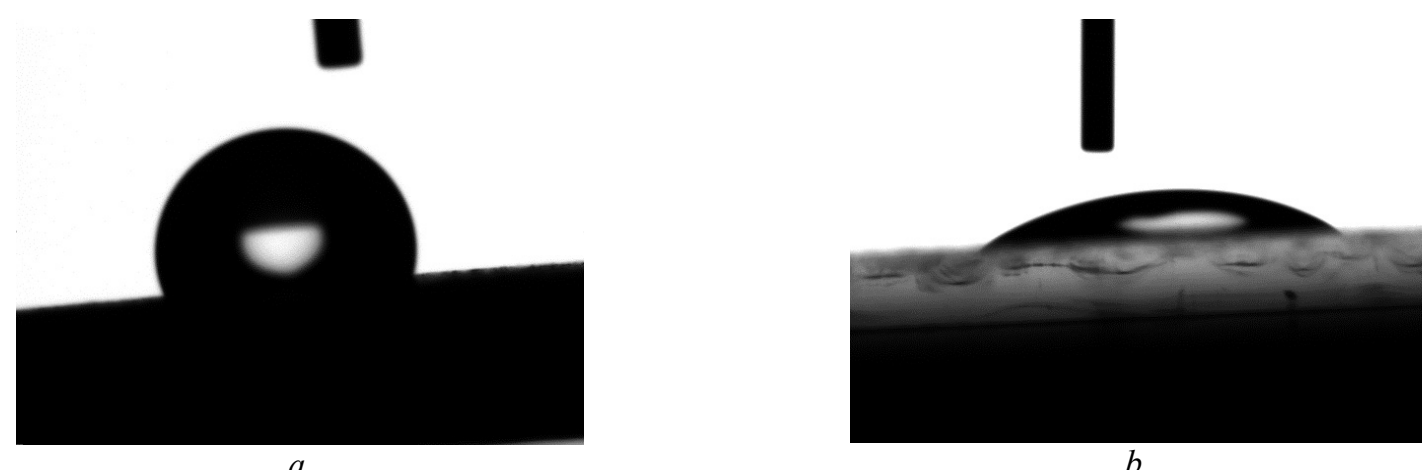

$a$ - absence of wetting; $b$ - wetting

Figure 5. Studying the wetting process of highly dispersed PTFE

We were interested into studying the way surfactant molecules affect the wetting ability of powdered (PTFE). We calculated the free energy (FSE) of powdered PTFE by Zisman plot, it is $35 \mathrm{mN} \cdot \mathrm{m}^{-1}$ [17] (Fig. 5). Therefore, PTFE must be wetted by liquids which surface tension is lower than the specified value. 
Most of the studied solutions meet this condition. However, in practice, we were not able to achieve complete hydrophilization of the surface in both an individual surfactant and its compositions with isopropyl alcohol (IPA) [18] (the cosine values of the contact angle were negative), although the contact angle decreased with rising concentration of the mixture.

The negative influence of the roughness factor and the suboptimal HLB value, leading to the absence of wetting, can be removed with the help of compositions which contain alcohols with a longer alkyl radical length.

Indeed, the problem of hydrophilization of powder PTFE was solved by replacing IPA by IBA and IAA. Moreover, we observed the values of contact angles wich are less than 90 degrees. We could observe it near the maximum of the surface activity curve. The obtained experimental dependences of the wetting isotherms (Fig. 6,7) are symbatic: in the initial section of the isotherm, a sharp increase in the cosine of the contact angle is observed, then the character of the dependences takes on a smoother, and sometimes stepped shape. The cosine of the contact angle of the composition at the wetting inversion point reduces with rising length of the alcohol radical. So, for the composition SAFOL 23 - IBA - water, the concentration at the inversion point was $0.51 \mathrm{~mol} \cdot \mathrm{L}^{-1}$, for the composition SAFOL 23 - IAA - water $-0.27 \mathrm{~mol} \cdot \mathrm{L}^{-1}$. This phenomenon and the growth in the steepness of the wetting isotherms indicate a more intense adsorption of the composition with an increase in the length of the alkyl radical on the surface of highly dispersed PTFE.

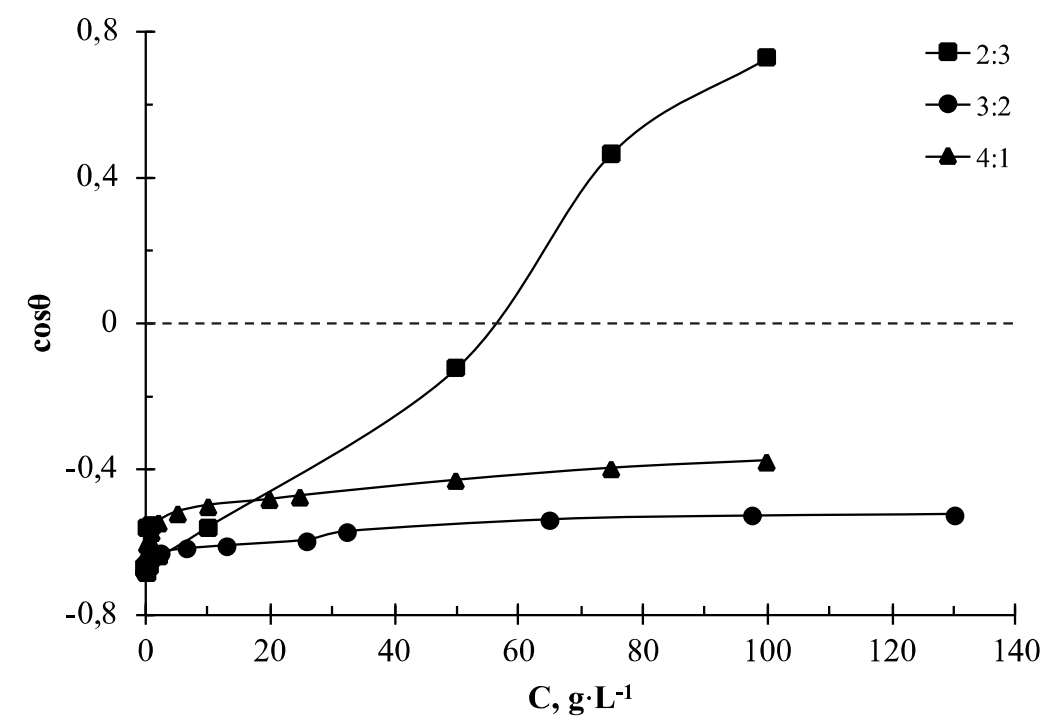

Figure 6. The contact angle isotherms of compositions at different ratios SAFOL 23:IBA

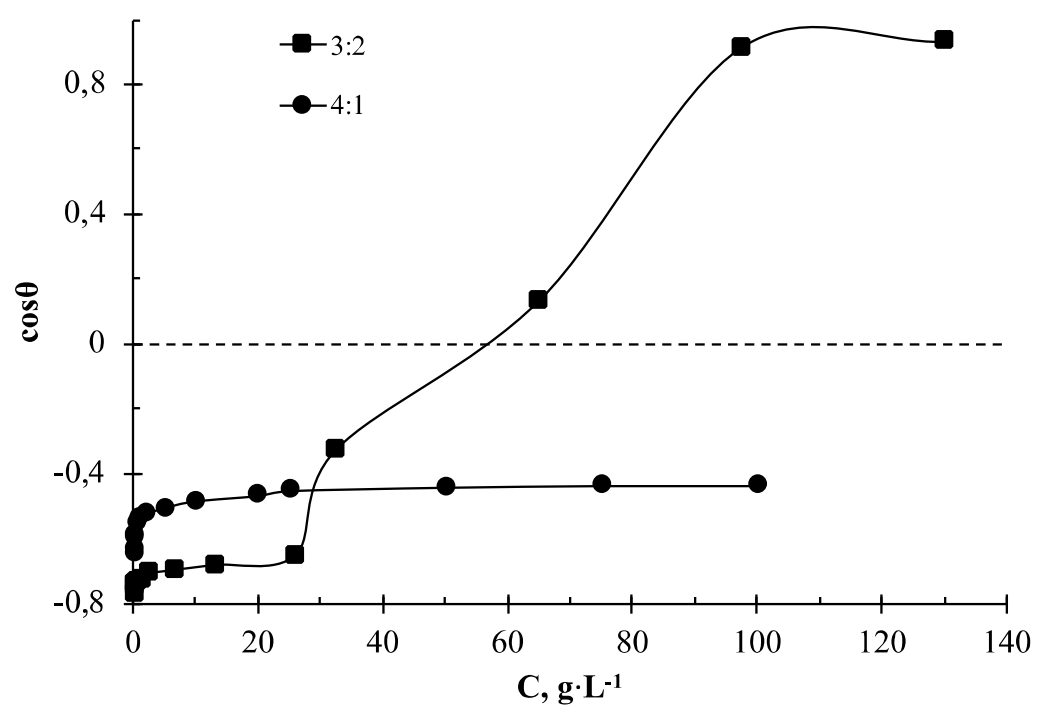

Figure 7. The contact angle isotherms of compositions at different ratios SAFOL 23:IAA 
It is possible to calculate the adsorption isotherm at the liquid-gas and the solid-liquid interfaces by formulas (3), (4). This calculation was carried out for the wetting compositions SAFOL 23 - IBA - water and SAFOL 23 - IAA - water. Figures 8, 9 show the adsorption isotherms of these compositions at the liquid-gas and the solid-liquid interfaces.

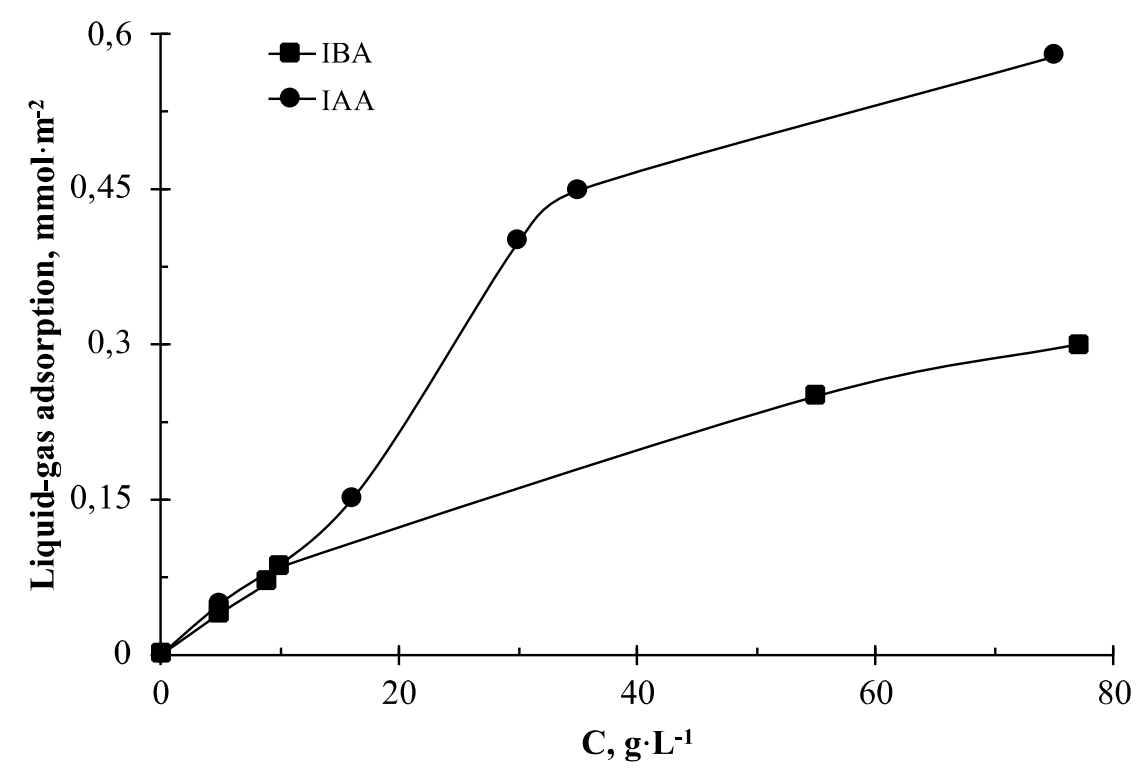

Figure 8. Liquid-gas adsorption isotherm of water-alcohol compositions based on SAFOL 23

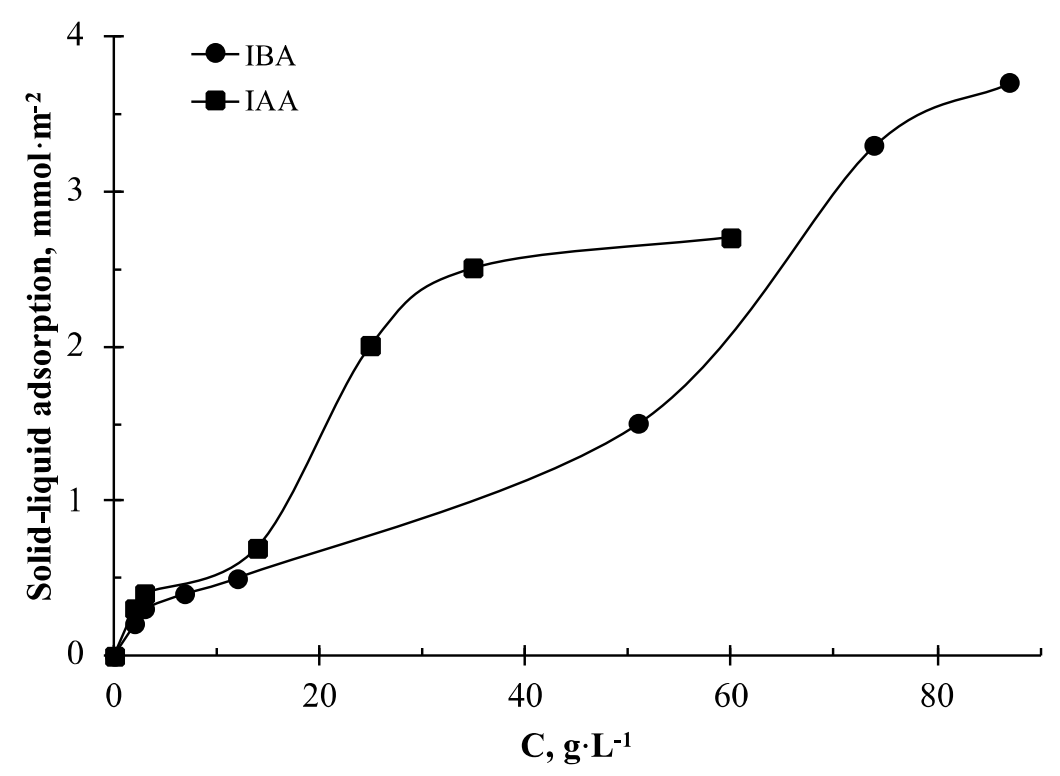

Figure 9. Solid-liquid adsorption isotherm of water-alcohol compositions based on SAFOL 23

The isotherms obtained for the solid-liquid interface are s-shaped and correspond to the scenario of weak interaction of the hydrophilic parts of surfactant molecules and the substrate [19] due to the high hydrophobicity of PTFE. As the concentration of the composition increases, the solvent composition changes. Alcohol molecules that are not included in the micelles appear in the dispersion medium. This affects the course of the further adsorption process and the organization of surfactant layers at the phase boundary.

At concentrations lower than $10 \mathrm{~g} \cdot \mathrm{L}^{-1}$, both compositions behave in a similar way, and the quantitative adsorption values practically coincide. In the region of higher concentrations both at the liquid-gas interface and at the solid-liquid interface, SAFOL 23 compositions with IAA exhibit a significantly higher adsorption capacity compared to compositions with IBA.

From the data presented in Figures 8, 9, it follows that the studied compositions are more adsorbed at the surface of the solid phase than at the liquid-gas interface. 
The appending of alcohol into an aqueous surfactant solution and the inclusion of its molecules in micelles change the ratio of hydrophilic and lipophilic groups which are reflected in the HLB value [18]. This characteristic was calculated for the mass ratio SAFOL 23:alcohol = 3:2 (Table 3). The obtained experimental results were compared with theoretical values calculated by equation (6). The HLB values of IBA and IAA were calculated according to equation (7), they amounted to 4.6 and 3.9, respectively.

$\mathrm{Tab}$ e 3

HLB determination results

\begin{tabular}{|l|c|c|c|}
\hline \multirow{2}{*}{ Composition } & \multirow{2}{*}{ Cloud point, ${ }^{\circ} \mathrm{C}$} & \multicolumn{2}{c|}{ HLB } \\
\cline { 3 - 4 } & & experimental & theoretical \\
\hline SAFOL 23 - water & 62 & 10.1 & 10.1 \\
\hline SAFOL 23 - IBA - water & 40 & 7.9 & 7.9 \\
\hline SAFOL 23 - IAA - water & 32 & 7.2 & 7.6 \\
\hline
\end{tabular}

Unlike the composition SAFOL 23 - water, which has an HLB value of 10 and belongs to the class of emulsifiers, the compositions SAFOL 23 - IBA - water and SAFOL 23 - IAA - water have substantially lower HLB, which allows them to be classified as lipophilic in nature wetting materials with low surface energy $[3,11]$, which was implemented in practice.

Thus, a growth in the length of the alcohol radical allowed us to reduce the HLB of compositions based on non-ionic surfactants SAFOL 23 and to increase their wetting ability in relation to a highly dispersed lowenergy surface.

Based on the performed experiment, it can be concluded that by varying the nature of alcohol, it is possible to regulate the functional properties of surfactants, which significantly expands the scope of their application.

\section{Conclusions}

Some conclusions can be drawn from the research results. The mutual attraction of surfactant-alcohol molecules in the mixed micelle weakens with increasing length of the alkyl radical. The composition of mixed micelles weakly depends on the ratio of components in the composition and the nature of the alcohol. The wetting ability of the compositions growths with increasing length of the alkyl radical. The use of longer chain alcohols in the composition with SAFOL 23 allows one to achieve an in-version of wetting and hydrophilize the low-energy highly dispersed PTFE surface at lower surfactant concentrations. Adsorption of water - alcohol compositions at the solid phase is more intense than at the liquid-gas interface. The appending of alcohols changes the hydrophilic-lipophilic balance of SAFOL 23, which allows it to be used as a solubilizer, emulsifier or wetting agent. Varying the nature of alcohol, it is possible to regulate the functional properties of surfactants, which significantly expands their application.

\section{References}

1 Холмберг К. Поверхностно-активные вещества и полимеры в водных растворах / К. Холмберг, Б. Йенссон, Б. Кронберг, Б. Линдман; пер. с англ. - М.: БИНОМ. Лаборатория знаний, 2007. - 528 с.

2 Саутина Н.В. Адсорбционное модифицирование поверхности полимеров водными растворами оксиэтилированных алкилфенолов / Н.В. Саутина, С.А. Богданова, В.П. Барабанов // Вестн. Казан. технол. ун-та. — 2009. — № 2. — С. $78-83$.

3 Поверхностно-активные вещества: синтез, свойства, анализ, применение / К.Р. Ланге; под науч. ред. Л.П. Зайченко. - СПб.: Профессия, 2007. - 240 с.

4 Шилова С.В. Влияние пропанола-1 на мицеллообразование алкилсульфатов натрия в водных растворах / С.В. Шилова, Т.С. Фалалеева, А.Я. Третьякова // Химия и хим. технол. — 2014. — Т. 57, № 7. — С. 57-60.

5 Site of Sasol Olefins \& Surfactants Gmbh. Company. — URL: https://www.sasol.com.

6 Kossen N.W. The determination of the contact angle for systems with powder / N.W. Kossen, P.M. Heertjes // Chemical Engineering Science. - 1965. - Vol. 20, Iss. 6. - P. 593-599.

7 Drelich J. Improved Sample Preparation and Surface Analysis Methodology for Contact Angle Measurements on Coal (Heterogeneous) Surfaces / J. Drelich, J.S. Laskowski, M. Pawlik // Coal Preparation. — 2000. — Vol. 21. — P. 247-275.

8 Holland P.M. Nonideal multicomponent mixed micelle model / P.M. Holland, D.N. Rubingh // The Journal of Physical Chemistry. - 1983. - Vol. 87, Iss. 11. - P. 1984-1990.

9 Rosen J.M. Surfactants and Interfacial Phenomena / J.M. Rosen — New York, NJ: John Wiley and Sons, 2012. — 455 p. 
10 Неионогенные поверхностно-активные вещества, полученные на основе окиси этилена и смеси неионогенных поверхностно-активных веществ. Определение температуры помутнения: ГОСТ Р 50346-92 (ISO 1065-91). - [Введен в действие от 1992-10-14]. - М.: Стандартинформ Российской Федерации, 1992. - 10 с. - (Национальный стандарт Российской Федерации).

11 Поверхностно-активные вещества и композиции: справ. / под ред. М.Ю. Плетнева. - М.: ООО «Фирма Клавель», 2002. - $768 \mathrm{c}$.

12 Szymczyk K. Behaviour of cetyltrimethylammonium bromide, Triton X-100 and Triton X-114 in mixed monolayer at the (water-air) interface / K. Szymczyk, A. Zdziennicka, J. Krawczyk, B. Janczuk // The Journal of Chemical Thermodynamics. — 2014. - Vol. 69. - P. 85-92.

13 Щекин А.К. Кинетика мицеллообразования при учете слияния распада сферических и цилиндрических мицелл / А.К. Щекин, М.С. Кшевецкий, О.С. Пелевин // Коллоид. журн. — 2011. — Т. 73, № 3. - С. 404-414.

14 Иванова Н.И. Мицеллообразование и поверхностные свойства водных растворов бинарных смесей Твин- 80 и бромида цетилтриметиламмония / Н.И. Иванова // Вестн. Моск. ун-та. Сер. 2. Химия. — 2012. — Т. 53, № 1. — С. 44-49.

15 Ляпунов Н.А. Поверхностно-активные, коллоидно-мицеллярные и антибактериальные свойства некоторых катионных антисептиков / Н.А. Ляпунов, А.В. Пуртов, Е.В. Дунай // Фармация. — 2013. — № 4. — С. 44-47.

16 Зимон А.Д. Адгезия жидкости и смачивание / А.Д. Зимон. - М.: Химия, 1974. — 416 с.

17 Корнилицина Е.В. Влияние степени дисперсности материала на величину свободной поверхностной энергии полимера / Е.В. Корнилицина, М.Г. Щербань, Н.В. Бабикова // Материалы Междунар. науч. конф., посвящ. 100-летию каф. орг. хим. ПГНИУ (16-18 мая 2018 г.). - Пермь: Изд-во Пермск. гос. нац. исслед. ун-та, 2018. — С. 236-238.

18 Щербань М.Г. Влияние изопропилового спирта на поверхностно-активные свойства SAFOL 23 / М.Г. Щербань, А.Д. Соловьев, А.О. Саляхова // Вестн. Пермск. ун-та. Сер. Химия. - 2020. - Т. 10, № 2. - С. 320-339.

19 Ролдугин В.И. Физикохимия поверхности: учеб.-моногр. / В.И. Ролдугин. — Долгопрудный: Изд. дом «Интеллект», 2011. $-568 \mathrm{c}$.

\author{
М.Г. Щербань, А.Д. Соловьев, А.О. Саляхова
}

\title{
SAFOL 23 - спирт - су жүйелерінің беттік-белсенді сипаттамаларының алкилді радикал спирттің ұзындығына тәуелділігі
}

\begin{abstract}
Изобутил (ИБС) және изоамил (ИАС) спирттерінің SAFOL 23 ионогенді емес беттік-белсенділік сипаттамаларының әсері зерттелді. Белсенді активті заттар (БАЗ) су ерітіндісінің және оның сулыспирттік композицияларының беттік керілу изотермалары (БКИ) алынды. Олардың негізінде SAFOL 23 сулы-спирттік жүйелері үшін аралас мицелланың құрамы және мицелледегі БАЗ өзара іс-қимыл факторының шамасы есептелген. Су-спирттік композицияның құрамы мен беттік-белсенділігі табылды және зерттелді. Беттік-белсенділіктің тәуелділігі SAFOL 23 қатынасынан: спирт монотонды сипатта болмайды және оның со-БАЗ со-еріткішке ауысуына байланысты максимум өтеді. Жоғары дисперсті политетрафторэтилен (ПТФЭ) SAFOL 23 сулы-спирттік композицияларымен жұқтыру процесі зерттелді. ПТФЭ беті гидрофизденді, тек беттік-белсенділіктің құрамына тәуелділік графигіндегі максимумға сәйкес келетін ерітінділерді пайдалану кезінде. Әр түрлі фазааралық шекараларда SAFOL 23 адсорбцияланған мөлшері мен оның концентрациясы арасындағы байланыс графиктері есептелген. SAFOL 23 ПТФЭ бетінде жақсы адсорбцияланады және ерітінді-газ шекарасында біршама әлсіз. Спиртті БАЗ су ерітіндісіне енгізу композицияның гидрофильді және липофильді топтарының саны арасындағы арақатынасты өзгертеді, бұл оның гидрофильді-липофильді балансының (ГЛБ) шамасына және лайланған температурасына әсер етеді. Бұл БАЗ қолдану ауқымын едәуір кеңейтеді және SAFOL 23 солюбилизатор, эмульгатор және гидрофилизатор ретінде пайдалануға мүмкіндік береді.
\end{abstract}

Кілт сөздер: ионогенді емес БАЗ, мицеллоқұрылым аралас мицеллолар, беттік белсенділік, адсорбция, дымқылдандыру, гидрофильді-липофильді баланс.

\section{М.Г. Щербань, А.Д. Соловьев, А.О. Саляхова \\ Зависимость поверхностно-активных характеристик систем SAFOL 23 - спирт - вода от длины алкильного радикала спирта}

Исследовано влияние изобутилового (ИБС) и изоамилового (ИАС) спиртов на поверхностно-активные характеристики неионогенного поверхностно-активного вещества (ПАВ) SAFOL 23. Получены изотермы поверхностного натяжения (ИПН) водного раствора ПАВ и его водно-спиртовых композиций. На основе серии ИПН ряда систем SAFOL 23 - спирт - вода рассчитаны составы смешанных мицелл и величины фактора взаимодействия ПАВ в мицелле. Найдена и изучена зависимость поверхностной 
активности водно-спиртовой композиции от ее состава. Зависимость поверхностной активности от соотношения SAFOL 23: спирт носит немонотонный характер и проходит через максимум, что связано с изменением функции спирта с ростом его содержания и переходу от со-ПАВа к со-растворителю. Авторами изучен процесс смачивания высокодисперсного политетрафторэтилена (ПТФЭ) композициями SAFOL 23 - спирт - вода, построены изотермы краевого угла смачивания. Поверхность гидрофилизировалась при соотношениях, которые находились в интервале максимума кривой зависимости поверхностной активности - состав композиции. Построены изотермы адсорбции на границах раздела фаз жидкость-газ, твердое тело-жидкость. SAFOL 23 в большей степени адсорбируется на поверхности твердой фазы, чем на границе жидкость-газ. Введение спирта в водный раствор ПАВ изменяет соотношение между числом гидрофильных и липофильных групп композиции, что отражается на величине ее гидрофильно-липофильного баланса (ГЛБ) и температуре помутнения. Это существенно расширяет диапазон применения ПАВ и позволяет использовать SAFOL 23 в качестве солюбилизатора, эмульгатора и смачивателя.

Ключевые слова: неионогенное ПАВ, мицеллообразование, смешанные мицеллы, поверхностная активность, адсорбция, смачивание, гидрофильно-липофильный баланс.

\section{References}

1 Holmberg, K., Jonsson, B., Kronberg, B., \& Lindman, B. (2007). Poverkhnostno-aktivnye veshchestva i polimery v vodnykh rastvorakh [Surfactants and polymers in aqueous solutions]. Moscow: BINOM; Laboratoriia znanii [in Russian].

2 Sautina, N.V., Bogdanova, S.A., \& Barabanov, V.P. (2009). Adsorbtsionnoe modifitsirovanie poverkhnosti polimerov vodnymi rastvorami oksietilirovannykh alkilfenolov [Adsorption modification of the surface of polymers with aqueous solutions of ethoxylated alkyl phenols]. Vestnik Kazanskoho tekhnolohicheskoho universiteta - Bulletin of Kazan Technological University, 2, 78 83 [in Russian].

3 Lange, K.R., \& Zaichenko, L.P. (Eds.) (2007). Poverkhnostno-aktivnye veshchestva: sintez, svoistva, analiz, primenenie [Surfactants: synthesis, properties, analysis, application]. Saint Petersburg: Professiia [in Russian].

4 Shilova, S.V., Falaleeva, T.S., \& Tretyakova, A.Ya. (2014). Vliianie propanola-1 na mitseloobrazovanie alkilsulfatov natriia $\mathrm{v}$ vodnykh rastvorakh [The effect of propanol-1 on the micelle formation of sodium alkyl sulfates in aqueous solutions]. Khimiia $i$ khimicheskaia tekhnolohiia - Chemistry and chemical technology, 57, 7, 57-60 [in Russian].

5 Site of Sasol Olefins \& Surfactants Gmbh. Company. Retrieved from https://www.sasol.com.

6 Kossen, N.W., \& Heertjes, P.M. (1965). The determination of the contact angle for systems with powder. Chemical Engineering Science, 20, 6, 593-599.

7 Drelich, J., Laskowski, J.S., \& Pawlik, M. (2000). Improved Sample Preparation and Surface Analysis Methodology for Contact Angle Measurements on Coal (Heterogeneous) Surfaces. Coal Preparation, 21, 247-275.

8 Holland, P.M., \& Rubingh, D.N. (1983). Nonideal multicomponent mixed micelle model. The Journal of Physical Chemistry, $87,11,1984-1990$.

9 Rosen, J.M. (2012). Surfactants and Interfacial Phenomena. New York, NJ: John Wiley and Sons.

10 Neionohennye poverkhnostno-aktivnye veshchestva, poluchennye na osnove okisi etilena i smesi neionohennykh poverkhnostno-aktivnykh veshchestv. Opredelenie temperatury pomutneniia [Nonionic surfactants, ethylene oxide-based substances and mixtures of nonionic surfactants. Determination of cloud point]. (1992). HOST R 50346-92 (ISO 1065-91) from 14 ${ }^{\text {th }}$ October 1992. Moscow: Standartinform Rossiiskoi Federatsii [in Russian].

11 Pletnev, M.Yu. (Eds.) (2002). Poverkhnostno-aktivnye veshchestva i kompozitsii: Spravochnik [Surfactants and compositions. Directory]. Moscow: OOO «Firma Klavel» [in Russian].

12 Szymczyk, K., Zdziennicka, A., Krawczyk, J., \& Janczuk, B. (2014). Behaviour of cetyltrimethylammonium bromide, Triton X-100 and Triton X-114 in mixed monolayer at the (water-air) interface. The Journal of Chemical Thermodynamics, 69, 85-92.

13 Shchekin, A.K., Ksheveckij, M.S., \& Pelevin, O.S. (2011). Kinetika mitselloobrazovaniia pri uchete sliianiia raspada sfericheskikh i tsilindricheskikh mitsell [Kinetics of micelle formation when taking into account the merger of the decay of spherical and cylindrical micelles]. Kolloidnyi zhurnal - Colloid journal, 73, 3, 404-414 [in Russian].

14 Ivanova, N.I. (2012). Mitselloobrazovanie i poverkhnostnye svoistva vodnykh rastvorov binarnykh smesei Tvin- $80 \mathrm{i}$ bromida tsetiltrimetilammoniia [Micelle formation and surface properties of aqueous solutions of binary mixtures of Tween-80 and cetyltrimethylammonium bromide]. Vestnik Moskovskoho universiteta. Seriia 2. Khimiia - Bulletin of Moscow University. Series 2. Chemistry, 53, 1, 44-49 [in Russian].

15 Lyapunov, N.A., Purtov, A.V., \& Dunai, E.V. (2013). Poverkhnostno-aktivnye, kolloidno-mitselliarnye i antibakterialnye svoistva nekotorykh kationnykh antiseptikov [Surface-active, colloidal micellar and antibacterial properties of certain cationic antiseptics]. Farmatsiia - Pharmacy, 4, 44-47 [in Russian].

16 Zimon, A.D. (1974). Adheziia zhidkosti i smachivanie [Fluid adhesion and wetting]. Moscow: Khimiia [in Russian].

17 Kornilicina, E.V., Shcherban', M.G., \& Babikova, N.V. (2018). Vliianie stepeni dispersnosti materiala na velichinu svobodnoi poverkhnostnoi enerhii polimera [The effect of the degree of dispersion of the material on the amount of free surface energy of the polymer]. Proceedings from Mezhdunarodnaia nauchnaia konferentsiia, posviashchennaia 100-letiiu kafedry orhanicheskoi 
khimii PGNIU - International scientific conference dedicated to the 100th anniversary of the Department of Organic Chemistry PSU (16-18 maia 2018 h.), (p. 236-238). Perm: PGNIU Publ. [in Russian].

18 Shcherban, M.G, Solovev, A.D., \& Salyahova, A.O. (2020). Vliianie izopropilovoho spirta na poverkhnostno-aktivnye svoistva SAFOL 23 [Influence of isopropyl alcohol on the surface-active properties of SAFOL 23]. Vestnik Permskoho universiteta. Seriia Khimiia - Bulletin of Perm University. Chemistry, 10, 2, 320-339 [in Russian].

19 Roldugin, V.I. (2011). Fizikokhimiia poverkhnosti: uchebnik-monohrafiia [Physical Chemistry of the Surface: Monograph Textbook]. Dolgoprudnyi: Izdatelskii dom «Intellekt» [in Russian].

\section{Information about authors}

Shcherban', Marina Grigoryevna - Candidate of chemical sciences, Assistant professor of Physical Chemistry Department, Perm State National Research University, Bukireva street, 614990, Perm, Russia; e-mail: ma-sher74@mail.ru; https://orcid.org/0000-0002-6905-6622.

Solovyev, Aleksandr Dmitriyevich $-2^{\text {nd }}$ year student (specialist), Perm State National Research University, Bukireva street, 614990, Perm, Russia; e-mail: solovev_s92@mail.ru; https://orcid.org/0000-00027852-3683.

Saliakhova, Anna Olegovna — graduate of the Physical Chemistry Department, Perm State National Research University, Bukireva street, 614990, Perm, Russia; e-mail: sapronova1995@yandex.ru. 